\title{
Startup Entrepreneur Support for Design and Development of Problem Statement to Product Finalization: A Case Study
}

\author{
Dr. J. S. Awati ${ }^{1}$, Prof. A. M. Mulla², Dr. Seema S. Desai ${ }^{2}$, Prof. Pradip Bamane and Prof. S. Karanjkar ${ }^{3}$ \\ ${ }^{1}$ ETC Department, RIT, Sakharale, \\ ${ }^{2}$ Mechanical Department, RIT, Sakharale, \\ ${ }^{2}$ MBA Department, RIT, Sakharale \\ ${ }^{3}$ ElectricalDepartment, RIT, Sakharale \\ 1jayashree.awati@ritindia.edu, \\ ${ }^{2}$ abid.mulla@ritindia.edu,, ${ }^{2}$ seema.desai@ritindia.edu, ${ }^{3}$ pradip.bamane@ritindia.edu, ${ }^{4}$ shrikant.karanjakar@ritindia.edu
}

\begin{abstract}
The paper will guide entrepreneurs for idea generation and product finalization for entrepreneurship development. The paper demonstrates the stages of Product Finalization and Idea Generation to consider for the customer segments. A step by step empathy map for design and development of problem statement is described herewith. This concept will facilitate new start-up entrepreneurs for Product Finalization. Case Study method is demonstrated in this paper to finalize the idea of start-up.
\end{abstract}

Keywords: Product, Idea, Empathy Map, Idea, Start-up.

\section{Introduction}

Now a days there is a boom of start-ups in the market environment. Many new Start-ups are emerging with innovative ideas. Government of India is enthusiastically supporting for such pioneering initiatives. Government is providing funds and also low interest loans for such new star-ups is made available. Recently new educators are thinking of indulging in such initiative's. For starting any new business, first, every entrepreneur has to have a clear Idea about the business and a skeletal map of his/her Product Plan should be ready. He/she must define the clear problem statement of his idea as well as define a proper business objective. When any entrepreneur is thinking about finalizing the product, he/she is confused regarding the situation as, to consider the benefit of the customer first, or think about the product on priority basis, He/she is also perplexed about other parameters like, Should we think of solution to the problem primarily, or finance should be our main concern or do we worry about the marketing concern. Hence, the entrepreneur is in a dilemma of all such questions as to how to represent the problem statement?

\section{Literature review}

Neeraj K Pandey[1] conducted a research focused on factors affecting on entrepreneurial ecosystem in the metro cities in India. In this research, a regression model isdeveloped for the financial support for start-ups, which helps to develop the efficiency level of entrepreneurial ecosystem. In this research,the authors have identified the effect of education, institute, experience, gender and funding type etc. on the initial funding of a start-up.

Juha Saukkonen[2] conducted the research about the road from a student to start-up entrepreneur and an employee. This study focusses on the recognistion of developing entrepreneurial skills among the students. The stages identified in this research were Pre-study, Standard Studies, Project work, Active start-up work, Senior Expertise etc. The research has identified three key issues - i) Networking i.e Developing relationships and getting tasks to perform, ii) Trying i.e Representing skills and handle real-life business, iii) Learning i.e. developing ability to analyze the solutions or own work and with others. This mind-set can be help to develop entrepreneurial personality.

R. S. Kanchana, J. V. Divya and A. Ansalna Beegom[3] in their paper he authorshave defined 'Entrepreneur' as a person who has initiative, motivation and skills to setup an enterprise and who always focuses for high achievement. There are lots of challenges faced by the new entrepreneurs e. g. Framing Vision and Business Idea, Funding for Startup, Developing Team, identifying Right Location, to face competition, Unforeseen Business Challenges, Industrial Changes and Trends, negative mind-set, lack of infrastructural facilities, lack of marketing facilities, etc. So it is necessary to handle these challenges and achieve stability of the enterprise is an important task performed by the entrepreneur.

Darian Unger a \& Steven Eppinger[4] in their study says that, product development processes (PDPs) are the process to design new products and bring them to market. There are certain difficulties faced by the entrepreneur in selecting, designing \& developing new product. The researcher says that, only having the good idea for the new product is not enough, to successfully bring this product to the market, and develop right product development process require to become succeed in the market. 
Boyoung Kim, Hyojin Kim and Youngok Jeon[5] The researcher suggests that idea commercialization, goalorientation, entrepreneurs' competence is important success factor for design startups. This study focuses on determination of the key success factors of a design startup business. The courage to start a business is also important factor. The means of startups design need multifaceted points, which must include vision, goal and step-by-step mission in line with achieve sustainable growth. Start-ups having high risk of failure in comparison with existing businesses. The main reason behind risk of failure is limited availability of resources, lack of established channels with vendors and customers.

\section{Problem identified:}

- Specific target ordinance is not identified.

- Problem is not defined properly.

- Size of market is not defined correctly.

- Problem identified and solution on that is not focused.

Due to failure in designing a correct problem statement or lack of proper technique of product finalized, many start-ups have not survived the fierce competition of the market. For efficient and effective survival of start-ups appropriate product must be finalized.

\section{Objectives:}

- To support the design and development of problem statement.

- To deliberate the insights of customer needs and requirements.

- To support the design and development of product finalization.

\section{Research Methodology:}

Faculty members from various departments were chosen for the study. The course chosen for the study was Entrepreneurship Development (ED) track, floated to the semester VIII of the B.Tech engineering program. Questions were framed to undertake the study based on the course content. For evaluating the parameters of idea generation and product finalization, a feedback was taken from students enrolled for Entrepreneurship Development ED track (startup). This was further analysed and the results gained were presented graphically and hence, the outcome's were described.

\section{Design and Development of Problem Statement:}

Figure below represents the flow of problem statement finalization starting from customer as a priority and also product as a major concern.

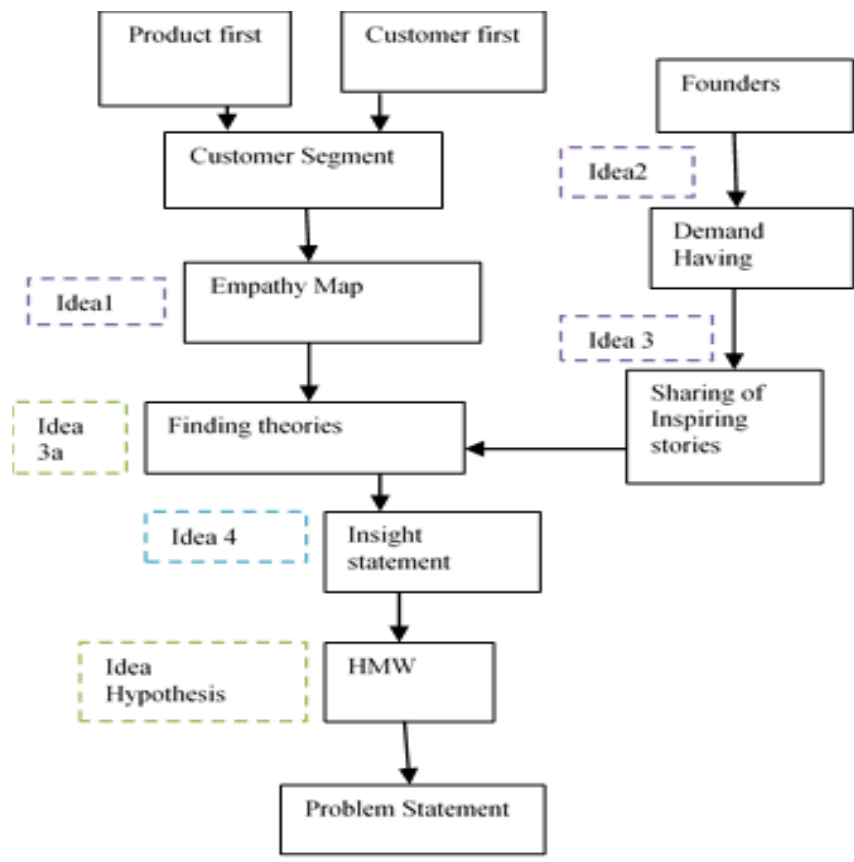

Fig.1 Overall block diagram of problem statement

The diagram represents the consideration of product and customer as a priority concern for customer segment. Customer segment is nothing but the target customer group selection based upon area and choice of the product. Identification of customer's for the product is done in customer segment. e.g. For purchase of Smart phone, the target customer base is majority young generations pertaining to their product needs. In this situation the schedule of the user is recorded and observed carefully. For example; To understand the routine schedule of a working women, the entire one-day time scheduling of the working women is given below: The schedule of the user is recorded and observed carefully.

Table1: Entire one day schedule of a working women:

\begin{tabular}{|c|c|}
\hline Time schedule & Activity \\
\hline 0 a.m. to 5.50 a.m. & Wake-up time \\
\hline n. to 6.00 a.m. & Getting Fresh \\
\hline a.m. to 6.15 a.m. & Tea and worship \\
\hline a.m. to 6.45 a.m. & $\begin{array}{l}\text { Cleaning the rooms, porch, drawing } \\
\text { Rangoli }\end{array}$ \\
\hline a.m. to 7.30 a.m. & $\begin{array}{l}\text { Preparation and serving the breakfast, } \\
\text { Arranging for washing machine }\end{array}$ \\
\hline a.m. to 8.15 a.m. & Preparation of food \\
\hline 8.45 a.m. & $\begin{array}{l}\text { Cleaning the utensils and pots, hanging } \\
\text { clothes for drying }\end{array}$ \\
\hline a.m. to 9.00 a.m. & Ready for office, packing Tiffin \\
\hline a.m. to 10.00 a.m. & Travelling to office \\
\hline 0 a.m. to 6.00 p.m. & Office working hours \\
\hline p.m. to 7.00 p.m. & Travelling back home \\
\hline p.m. to 7.15 p.m. & Getting Fresh and having tea \\
\hline p.m. to 8.45 p.m. & Preparation for dinner, serving food. \\
\hline p.m. to 9.30 p.m. & $\begin{array}{l}\text { Cleaning utensils, pots and dishes, guiding } \\
\text { children }\end{array}$ \\
\hline 10.00 p.m. & Preparation for second day \\
\hline p.m. to 11.00 & $\begin{array}{l}\text { Discussion with children and making bed } \\
\text { ready for sleeping. }\end{array}$ \\
\hline
\end{tabular}


Shown in fig. below is the Entire One day schedule of a male customer.

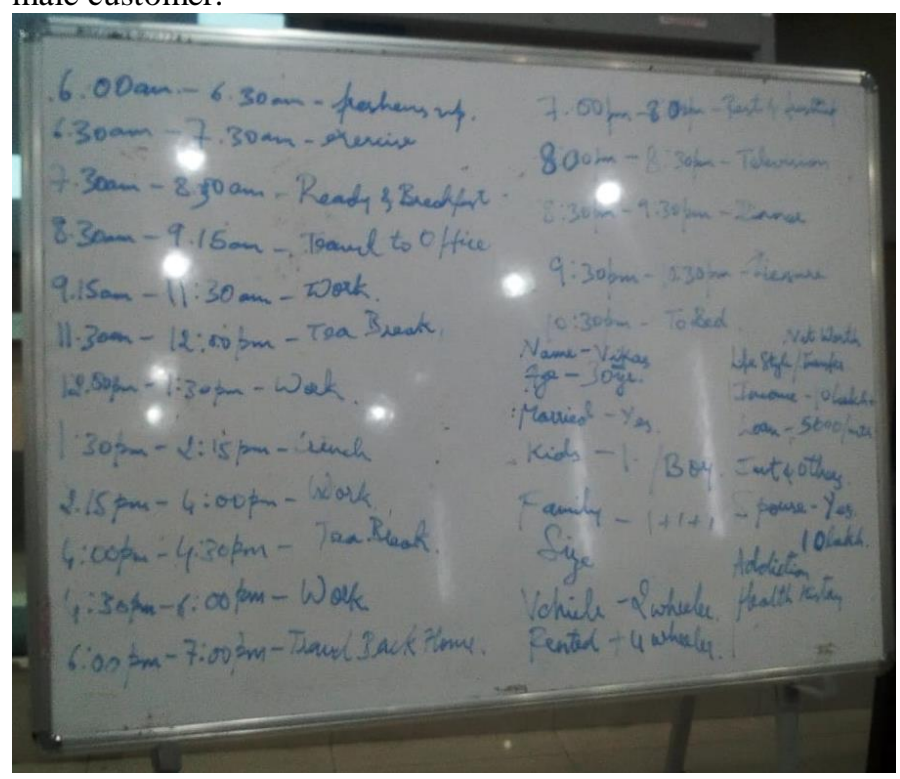

Fig 2. Entire One day Schedule of a male customer.

\section{Empathy Map:}

Empathy Map provides detail information regarding user. In traditional methods empathy map is divided into four parts where the user is a primary concern and hence, is depicted in the centre of the diagram. Rest of the four parts of the Empathy map diagram are Says, Thinks, Does and Feels of user or customer.

The traditional empathy map is described as below.

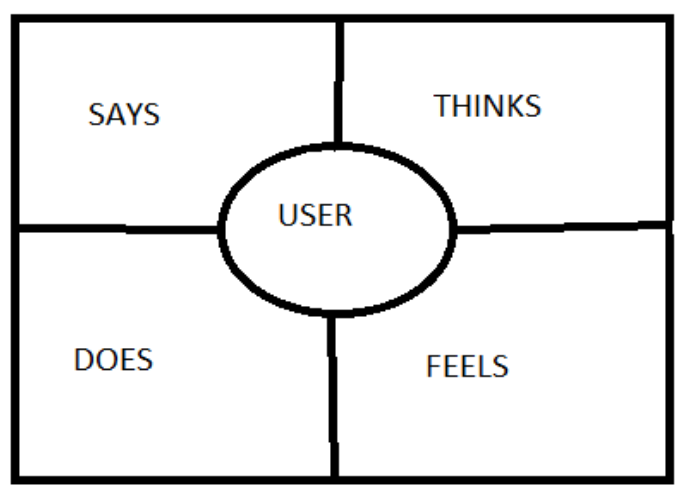

Fig.3 Traditional empathy map

The 'Says' parameter includes what normally the user or the customer says while thinking about purchasing a product. Such as:

I want something different.

I want .... this, I want that ......

The cost of the product should be low.

The device must be portable, handy and lifelong.

I want something durable, etc.

'Think' parameter contains discusses about, what the users are thinking throughout about their experience towards the product. To understand this segment a qualitative research should be undertaken by the entrepreneur. To understand Thinks parameter, a questionnaire design should be in such a manner that the developer should be able to find out what users are thinking before making a buying decision or what they will think after the usage of the product.

Example: "I am afraid of to use this kind of instrument"

"I don't want to use this product!"

"This product is not suitable for me."

"This product is not affordable, We won't be able to pay the amount", etc.

'Feels' parameter includes what the user of the product feels towards the product. Is he/she satisfied or unsatisfied regarding the usage of the product. It is very difficult to distinguish between the two parameters 'Think' and 'Feels'.

Example: If a user feels satisfied to use any product or want to buy that product, but due to price he/she is unable to buy that product. In this case we can say that, user feels happy to buy that product, so Feel parameter is defined and due to high price of the product, they are unable to buy that product. In this case the Thinks parameter of user is taken into consideration.

Example: Amruta likes the brand of BMW car's but cannot purchase the BMW car due to its affordability. In this case Feel parameter is addressed in like's the brand, but the Think parameter is not addressed, as she is unable to purchase due to high price of the car.

Does is a very important parameter in the empathy map. For this the developer must have some previous back records of purchases of customers or users. This parameter will help to analyze what normally the user is buying, where they are investing their money, how they are utilizing their earnings, resources, what is the frequency of purchase etc.

Example: Maruti or Honda car dealers mostly contact all the Professors in colleges, doctors, officers in different government organizations and non-government organizations. Because as per their records, the purchasing of cars is done mostly from such people who are in these jobs This parameter helps to fix marketing strategy and target such customer base.

There is a difference in one user empathy map to multiuser empathy map. To understand the difference in one user empathy map and multiuser empathy map developer must use qualitative analysis. For quantitative analysis the developer must set the target customer, which will help for sample size calculation. Sample size will be calculated by online sample size calculator e.g. www.surveysystem.com www.surveymonkey.com www.calculator.net/sample-size-calculator.html www.raosoft.com/samplesize.html www.quatricks.com/blog/calculating-sample-size 
www.npscalculator.com/de/signifiance

Now-a-days due to evolution in the research and development and analysis the traditional empathy map was modified. The new empathy map is demonstrated as below.



Fig..4 modified empathy map.

By considering the working women as a customer, the empathy map is given as below.

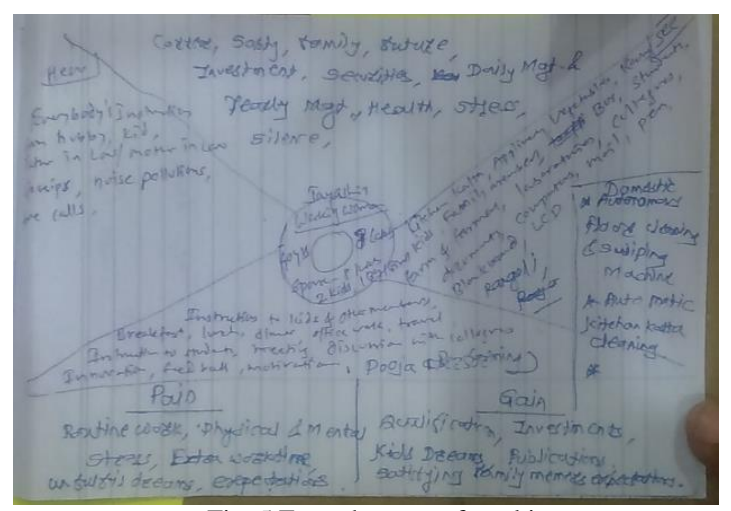

Fig. 5 Empathy map of working women

The different ideas for customer segment are listed in figure below. The group members generated different ideas through brainstorming. The ideas are pasted on card sheets.

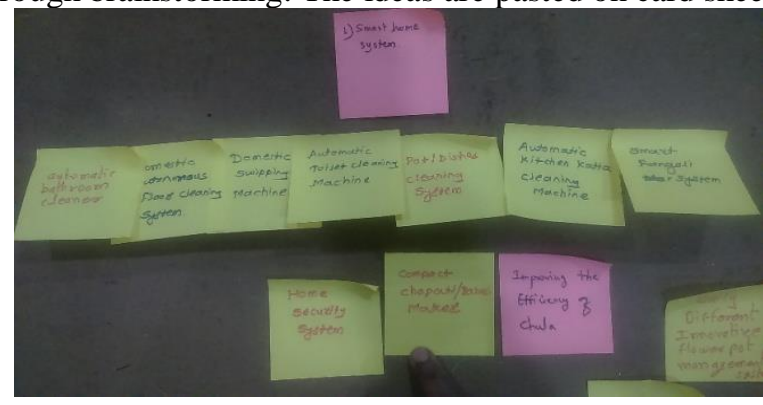

Fig.6. List of ideas.

Once the list of ideas are collected, then grouping of similar type of ideas is done.

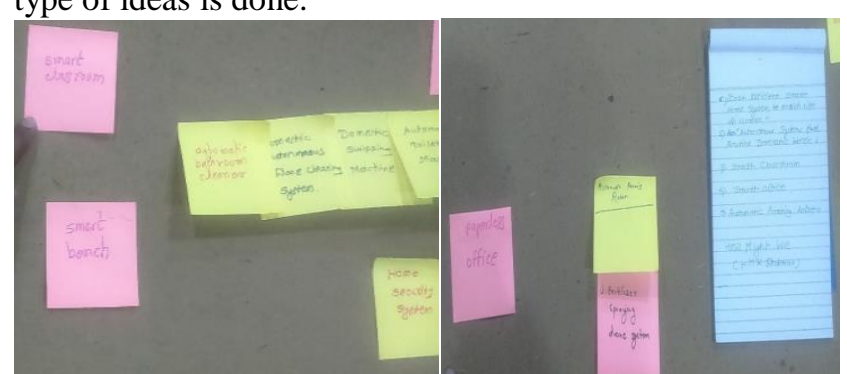

Fig.7. Grouping the similar types of ideas.
After grouping the similar types of idea, repeated idea's are cancelled whereby the filtering of best ideas can be done.

\section{Rubrics for selecting the Idea:}

Rubrics is designed to select the idea. The rubrics is as given below.

Table 2: Rubrics for selecting the idea

\begin{tabular}{|c|c|c|c|c|c|c|}
\hline \multirow[t]{2}{*}{ Criteria } & \multicolumn{6}{|c|}{$\begin{array}{c}\text { Idea }(1=\text { Low, } 2=\text { Mod. } 3=\text { Good, } 4= \\
\text { excellent })\end{array}$} \\
\hline & Idea 1 & Idea2 & Idea3 & Idea4 & Idea5 & $\begin{array}{l}\text { Final } \\
\text { Score }\end{array}$ \\
\hline $\begin{array}{l}\text { Fits in customer } \\
\text { segment }\end{array}$ & [ ] & [ ] & [ ] & {$[$ ] } & [ ] & \\
\hline $\begin{array}{l}\text { Evaluation of Empathy } \\
\text { map }\end{array}$ & {$[\quad]$} & {$[\quad]$} & [ ] & [ ] & [ ] & \\
\hline $\begin{array}{l}\text { Problem and solution is } \\
\text { identified. }\end{array}$ & [ ] & [ ] & [ ] & [ ] & [ ] & \\
\hline Target market analysis & & [ ] & [ ] & {$[$ ] } & [ ] & \\
\hline $\begin{array}{l}\text { Different / better / new } \\
\text { product }\end{array}$ & [ ] & [ ] & [ ] & [ ] & {$[$ ] } & \\
\hline $\begin{array}{l}\text { Cost, benefit and passion } \\
\text { factor analyzed. }\end{array}$ & [ ] & [ ] & [ ] & [ ] & [ ] & \\
\hline $\begin{array}{l}\text { Suitable to my skills or } \\
\text { skilled persons are } \\
\text { available }\end{array}$ & [ ] & [ ] & [ ] & {$[$ ] } & [ ] & \\
\hline
\end{tabular}

Based on final score of idea the product is finalized. Once the product is finalized, then the product design is selected. Initially multiple ways are tested for design finalization.

\section{Idea Hypothesis:}

Idea Hypothesis is scientific and educated prediction way to test the selected idea. Idea hypothesis supports for Idea validation which reduces the risk of idea failure.

Steps for idea hypothesis are as follows:

- State Idea Hypothesis

- Formulate an analysis plan

- Choose data collection method

- Analyze sample data

- Interpret results

- Discuss on Idea

\section{Problem Statement:}

In problem statement the pain and gain of customer must be stated effectively and innovatively. It is very easy to define the problem statement using following statement.

Customer needs a way to Need because Innovative Insights.

\section{Product design steps:}

Any product design contains the following steps:

- List the objectives of product

- Brainstorm the product among team

- Brainstorm the solution

- Develop porotypes and solution with objectives

- Discuss on solution 


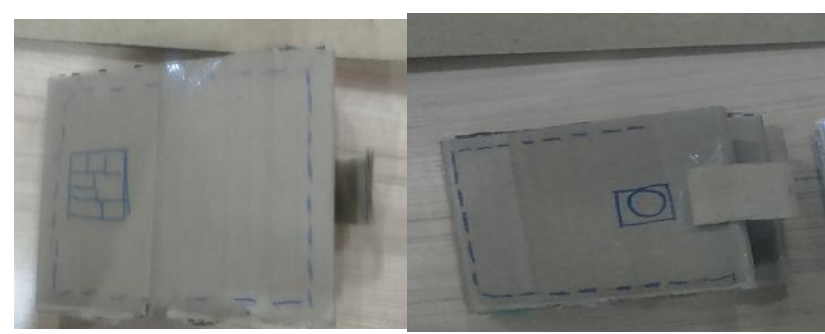

Fig. 8 Design presented at the time of discussion Fig. 8 represents the design finalized at the time of discussion which fulfils all the requirements of men customer's.

The next step after this is to develop a prototype and take the initial testing of products. Next step is to analyse the product and design. If required, certain modification's can be done at this early stage. The key features of products are listed below:

- Flexible product design

- Adoptable technology, continuous improvement

- Critical evaluation

- Customer feedback evaluation

\section{Data Collection:}

The data for this study is collected by the faculty members, Entrepreneurship Development ED track students, and startup entrepreneur's. For data collection questionnaire method is used. The questionnaire is given in table. 3 below.

Table 3: Questionnaire

\begin{tabular}{|c|c|c|c|c|c|}
\hline Questions & $\begin{array}{l}\text { Strongly } \\
\text { Agree (5) }\end{array}$ & $\begin{array}{l}\text { Moderately } \\
\text { Agree(4) }\end{array}$ & $\begin{array}{l}\text { Agree } \\
(3)\end{array}$ & $\begin{array}{l}\text { Neutral } \\
(2)\end{array}$ & $\begin{array}{l}\text { Disa } \\
\text { gree } \\
(1)\end{array}$ \\
\hline $\begin{array}{l}\text { Case study support for } \\
\text { idea generation and } \\
\text { selection }\end{array}$ & [ ] & [ ] & [ ] & [ ] & [ ] \\
\hline $\begin{array}{l}\text { Case study support for } \\
\text { product design and } \\
\text { development }\end{array}$ & [ ] & [ ] & [ ] & [ ] & [ ] \\
\hline $\begin{array}{l}\text { Case study support for } \\
\text { finalize the product }\end{array}$ & [ ] & [ ] & [ ] & [ ] & [ ] \\
\hline $\begin{array}{l}\text { Will you recommend } \\
\text { this case study to your } \\
\text { friends }\end{array}$ & [ ] & [ ] & [ ] & [ ] & [ ] \\
\hline $\begin{array}{l}\text { Need more details for } \\
\text { start-up. }\end{array}$ & {$\left[\begin{array}{ll}{[} & ]\end{array}\right.$} & [ ] & [ ] & [ ] & [ ] \\
\hline
\end{tabular}

\section{Results and discussion:}

The study was evaluated using faculty as well as students' feedback. For the study feedback is evaluated graphically.

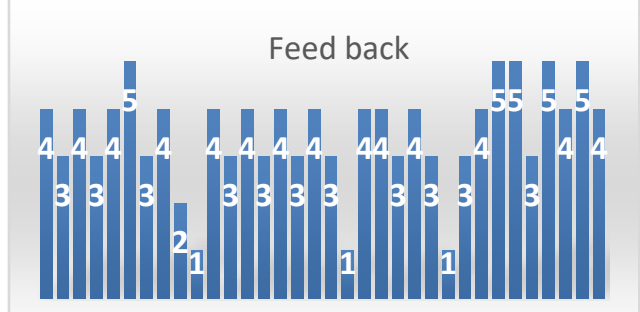

13579111315171921232527293133

Fig. 9. Feedback analysis

Fig. 9 shows that the case study is a very beneficial and useful method for start-ups. It also indicates that more details are required for designing a start-up. This requirement was given by three members.

\section{Conclusion:}

Entrepreneurship is an effective development tool for the journey form idea generation to product finalization. This paper framed has focused on the deep support given to the Entrepreneurship Development ED course. Faculty took care that few ideas were generated and developed and conclude to product finalize in a well-framed manner. Hence, Entrepreneurship development helps both course owners as well as the students to gain quickly a review of idea within a very short span of course material and finalize the product in a well-framed manner.

\section{Outcomes:}

The outcome of this students' activity was that students introduced their start up. Students were very much enthusiastic about the whole concept and they did take interests regarding the finalization of start-up project. Students agreed upon unanimously and accepted the fact that they would prefer to be job creator's instead of job finder's.

\section{References:}

1. Neeraj K. Pandey (2018) An Analysis of Startup Ecosystem in Metropolitan City in India, International Journal of Engineering and Management Research, Volume-8, Issue-2, 237-244.

2. Juha Saukkonen (2017) From a Student of Startup Business to a Startup Employee or Entrepreneur: Study on Career Narratives of Students in Entrepreneurial Programs in a University, Journal of Educational Issues, Vol. 3, No. 1, 214-235.

3. R. S. Kanchana, J. V. Divya and A. Ansalna Beegom (2013) Challenges faced by new entrepreneurs, International Journal of Currant Research \& Academic Review, Vol. 1, No. 3, 71-78.

4. Darian Unger a \& Steven Eppinger (2011) Improving product development process design: a method for managing information flows, risks, and iterations, Journal of Engineering Design, Vol. 22, No. 10, 689-699.

5. Boyoung Kim , Hyojin Kim and Youngok Jeon (2018), Case Report Critical Success Factors of a Design Start-up Business, Sustainability Journal,2-15,

\section{Acknowledgement}

This activity was supported by Entrepreneurship Development ED cell of Rajarambapu Institute of Technology. Thanks to the ED cell for promoting various entrepreneurship activities in the Institute. We express our sincere gratitude to our Director, Dean Academics, Heads and faculty of ETC, mechanical, Electrical and MBA department for their valuable inputs that greatly improved this manuscript. 